\title{
Pathomechanism of Insulin Resistance in Men with Central Obesity: Correlation of GGT, GPx, hs-CRP and Plasma Total Cysteine
}

\author{
Ritawaty $^{1,2}$, Indriyanti Rafi Sukmawati ${ }^{1,3}$, Ilhamjaya Patellongi ${ }^{1}$, Ferry Sandra ${ }^{3,4, *}$ \\ ${ }^{1}$ Postgraduate Program in Clinical Biochemistry, Hasanuddin University, Jl. Perintis Kemerdekaan Km.10, Makassar, Indonesia \\ ${ }^{2}$ Prodia Clinical Laboratory, Jl. Merbabu No.10, Malang, Indonesia \\ ${ }^{3}$ Prodia Clinical Laboratory, Jl. Kramat Raya No.150, Jakarta, Indonesia \\ ${ }^{4}$ Department of Biochemistry and Molecular Biology, Faculty of Dentistry, Trisakti University, Jl. Kyai Tapa No.260, Jakarta, Indonesia \\ *Corresponding author. E-mail: ferrysandra@gmail.com
}

\section{Abstract}

B ACKGROUND: Gamma glutamyltransferase (GGT) was reported recently to be associated with inflammation, oxidative stress and increased amino acid. However, role of GGT in insulin resistance pathomechanism is not exactly known. Therefore correlation of GGT with inflammation, oxidative stress and elevated amino acid, in men with central obesity need to be confirmed.

METHODS: A cross-sectional study was designed. Men with central obesity were recruited and selected. Anthropometric parameters, creatinine, hs-CRP, fasting glucose, fasting insulin, glutathione peroxidase (GPx) activity, GGT, plasma total cysteine (tCys) and fatty liver were measured. Subjects were then divided in 4 groups based on waist circumference (WC) and fatty liver: Group I: $\mathrm{WC} \leq 100 \mathrm{~cm}$, without fatty liver; Group II: $\mathrm{WC} \leq 100 \mathrm{~cm}$, with fatty liver; Group III: WC $>100 \mathrm{~cm}$, without fatty liver; Group IV: WC $>100 \mathrm{~cm}$, with fatty liver. All biochemical characteristics in each group were then statistically analyzed.

RESULTS: Seventy-two men with central obesity were selected. Numbers of subjects in each group were: Group I: $n=33$; Group II: $n=5$; Group III: $n=17$; Group IV: $n=17$. We found significant difference of HOMA-IR between Group I and IV, significant correlation between GGT and HOMAIR, and significant negative correlation between tCys with HOMA-IR in Group IV.

CONCLUSION: GGT was significantly correlated with HOMA-IR in men with $\mathrm{WC}>100 \mathrm{~cm}$ and fatty liver. Further investigation with more subjects is necessary to determine

\section{Abstrak}

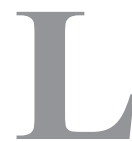

ATAR BELAKANG: Gammaglutamyltransferase (GGT) dilaporkan berhubungan dengan inflamasi, stres oksidatif dan peningkatan asam amino. Akan tetapi peran GGT pada patomekanisme resistensi insulin belum jelas. Oleh karena itu korelasi GGT dengan inflamasi, stres oksidatif dan peningkatan asam amino pada pria dengan obesitas sentral masih perlu dikonfirmasi.

METODE: Penelitian potong lintang didesain. Pria dengan obesitas sentral direkrut dan diseleksi. Parameter antropometrik, kreatinin, hs-CRP, glukosa puasa, insulin puasa, aktivitas glutathione peroxidase (GPx), GGT, plasma total cysteine ( $\mathrm{tCys}$ ) dan perlemakan hati dilakukan pengukuran. Subyek kemudian dibagi menjadi 4 kelompok berdasarkan lingkar pinggang (LP) dan perlemakan hati: Grup I: LP $\leq 100 \mathrm{~cm}$, tanpa perlemakan hati; Grup II: LP $\leq 100 \mathrm{~cm}$, dengan perlemakan hati; Grup III: LP $>100 \mathrm{~cm}$, tanpa perlemakan hati; Grup IV: LP $>100 \mathrm{~cm}$, dengan perlemakan hati. Kemudian semua karakteristik biokimia pada setiap grup dilakukan analisa statistik.

HASIL: Tujuh puluh dua pria dengan obesitas sentral diseleksi. Jumlah subyek pada masing-masing grup adalah: Grup I: n=33; Grup II: n=5; Grup III: n=17; Grup IV: n=17. Kami menemukan perbedaan bermakna pada HOMA-IR antara Grup I dan IV, korelasi bermakna antara GGT dan HOMA-IR, serta korelasi negatif bermakna antara tCys dengan HOMA-IR pada Grup IV.

KESIMPULAN: GGT berkorelasi bermakna dengan HOMA-IR pada pria dengan LP $>100 \mathrm{~cm}$ dan perlemakan hati. Penelitian lebih lanjut dengan subyek yang lebih 
clear GGT cut-off to distinguish subjects with fatty liver and insulin resistance.

KEYWORDS: GGT, hs-CRP, GPx, tCys, HOMA-IR, insulin resistance

Indones Biomed J. 2013; 5(2): 101-6 banyak dibutuhkan agar dapat menentukan cut-off GGT secara jelas sehingga dapat membedakan subyek dengan perlemakan hati dan resisten insulin.

KATA KUNCI: GGT, hs-CRP, GPx, tCys, HOMA-IR, resistensi insulin

\section{Introduction}

Obesity is one of metabolic syndrome major criteria, which related with cardiometabolic diseases, such as type 2 diabetes mellitus, hypertension and coronary heart disease.(1) Increased prevalence of obesity was closely related to prevalence of metabolic syndrome and increased cardiometabolic disease risk. Therefore, it is important to develop biomarker for observing progression from central obesity to metabolic syndrome.

Gamma glutamyltransferase (GGT), mostly produced in liver(2), involved in intracellular homeostasis to resynthesis glutathione (GSH) by maintaining the availability of cysteine(3). Initially, GGT was known as a biomarker for liver disease or excessive alcohol intake, but recent reports showed that GGT could be an independent predictor of risk cardiometabolic disease.(4,5) Elevated GGT in subject with metabolic syndrome was reported to have a correlation with central obesity, resistance insulin and hepatic steatosis.(6) However, role of GGT in insulin resistance pathomechanism is not exactly known. Several studies showed correlation of GGT with inflammation, oxidative stress(7-9) and elevated amino acid(10), that could be related with insulin resistance pathomechanism $(8,11)$.

C-reactive Protein (CRP), synthesized in the liver, is not only an acute phase protein, but also a marker of chronic low grade inflammation.(12) Several studies showed association of elevated CRP level with cardiovascular disease(13) and with abdominal obesity.(14) Meanwhile, glutathione peroxidase (GPx) that involves in detoxification of $\mathrm{H}_{2} \mathrm{O}_{2}$ and lipid peroxide by catalyzing $\mathrm{GSH}$, showes its important role to defense oxidative stress.(15) Lower GPx level was reported in obese patient than healthy subject.(14) Cysteine is an essential proteinogenic amino acid containing sulfur. Plasma total cysteine (tCys) contains all forms of cysteine in the circulation including free form, disulfide and cysteine-bound albumin.(16) tCys was reported to be associated with homeostatic model assessment insulin resistance index (HOMA-IR).(11)

To our current interest in finding a possible insulin resistance pathomechanism, we examined correlation of GGT with inflammation (high sensitivity CRP (hs-CRP)), oxidative stress (GPx) and elevated amino acid (tCys), in men with central obesity.

\section{Methods}

\section{Subjects}

Men with central obesity in Malang and Denpasar, aged 3060 years old, $\mathrm{WC} \geq 90 \mathrm{~cm}$, were recruited. Medical records were obtained. Subjects with hs-CRP $>10 \mathrm{mg} / \mathrm{L}$, estimated glomerular filtration rate (eGFR) $<60 \mathrm{~mL} /$ minute $/ 1.73 \mathrm{~m}^{2}$, hepatitis $\mathrm{B}$ and $\mathrm{C}$, cirrhosis, malignancy, vegetarian, smoking habit, and intake of alcohol, supplement, antioxidant or hepatotoxicity drugs, were excluded. This study was approved by the Ethics Committee of Hasanuddin University Faculty of Medicine (UH13020059), and written informed consent was obtained from each subject.

\section{Blood collection and biochemical analyses}

Venous blood samples were collected in the morning after 10-12 hours fasting, in plain, EDTA-contained and heparin-contained vacutainers. Plain and EDTA-contained vacutainers were then centrifuged.

Resulted serum in plain vacutainer was collected and examined for fasting glucose, hs-CRP, creatinine, GGT and fasting insulin. For fasting glucose assay, GLUC3 kit (Roche Diagnostics GmbH, Mannheim, Germany) was used. For hs-CRP assay, CRPHS kit (Roche Diagnostics $\mathrm{GmbH}$, Mannheim, Germany) was used. For creatinine assay, Creatinine plus ver.2 kit (Roche Diagnostics GmbH, Mannheim, Germany) was used. Autoanalyzer Cobas Integra 400 (Roche Diagnostics, Rotkreuz, Switzerland) was applied for fasting glucose, hs-CRP and creatinine assays.

For GGT assay, GGT kit (Bayer Healthcare, Tarrytown, NY) and Autoanalyzer ADVIA 1800 (Siemens Medical Solutions Diagnostics, Tarrytown, NY) were used. For fasting insulin assay, Immulite 2000 Insulin kit (Siemens 
Healthcare Diagnostics, Tarrytown, NY) and Immulite 2000 (Siemens Medical Solutions Diagnostics, Flanders, NJ) were used.

Resulted plasma in EDTA-contained vacutainer was collected and examined for tCys by using ClinRep Complete kit for Homocysteine in plasma (Recipe Chemicals \& Instruments GmbH, Munich, Germany) and Agilent 1100 HPLC (Agilent Technologies, Waldbronn, Germany).

Venous blood in heparin-contained vacutainer was collected and examined for GPx activity by using Glutathione Peroxidase kit (Randox Laboratories Limited, Crumlin, County Antrim) and Autoanalyzer ADVIA 1800 (Siemens Medical Solutions Diagnostics, Tarrytown, NY). Each assay was performed according to the protocol provided in each kit. Fatty liver check was performed with abdominal ultrasonography (Logic 3 Pro, General Electric Co, Milwaukee, WI). Fatty liver and its grades (I, II and III) were determined by a radiologist.

\section{Statistical analysis}

Statistical analysis was performed using IBM SPSS for Windows version 19.0 (IBM Corp., Armonk, NY). All values are expressed as mean \pm standard deviation (SD), unless otherwise specified. Mann Whitney and Spearman analyses were used at a significance level of $p \leq 0.05$.

\section{Results}

Anthropometric and biochemical characteristics of 72 men with central obesity, aged $42.4 \pm 8.7$ (range: $30-60$ years) and the mean of WC was $100.3 \pm 6.9$ (range: $90-128 \mathrm{~cm}$ ), were obtained and shown in Table 1. Among the subjects with $\mathrm{WC} \leq 100 \mathrm{~cm}$, we found 5 subjects with fatty liver (3 subjects with fatty liver grade I and 2 subjects with fatty liver grade II). Meanwhile among the subjects with WC $>100 \mathrm{~cm}$, we found 17 subjects with fatty liver (4 subjects with fatty liver grade I, 5 subjects with fatty liver grade II, and 8 subjects with fatty liver grade III). All Subjects were then grouped based on WC and fatty liver: Group I: WC $\leq 100 \mathrm{~cm}$, without fatty liver, $\mathrm{n}=33$; Group II: $\mathrm{WC} \leq 100 \mathrm{~cm}$, with fatty liver, $\mathrm{n}=5$; Group III: $\mathrm{WC}>100 \mathrm{~cm}$, without fatty liver, $\mathrm{n}=17$; Group IV: $\mathrm{WC}>100 \mathrm{~cm}$, with fatty liver, $\mathrm{n}=17$.

Table 1. Anthropometric and biochemical characteristics of subjects

\begin{tabular}{lcccc}
\multicolumn{1}{c}{ Variable } & Mean \pm SD & Median & Min & Max \\
\hline Age (years) & $42.40 \pm 8.70$ & 41.50 & 30 & 60 \\
WC $(\mathrm{cm})$ & $100.30 \pm 6.90$ & 99 & 90 & 128 \\
Height $(\mathrm{cm})$ & $167.90 \pm 6.10$ & 167.30 & 154 & 181 \\
Weight $(\mathrm{Kg})$ & $80.30 \pm 10.50$ & 78.20 & 63 & 125 \\
BMI $\left(\mathrm{Kg} / \mathrm{m}^{2}\right)$ & $28.40 \pm 2.80$ & 27.90 & 24 & 39 \\
Hb (g/dL) & $15.70 \pm 1.00$ & 15.60 & 14 & 18 \\
GGT (U/L) & $44.20 \pm 12.80$ & 35 & 14 & 178 \\
Fasting Glucose $(\mathrm{mg} / \mathrm{dL})$ & $97.60 \pm 26.80$ & 90.50 & 77 & 235 \\
Fasting Insulin $(\mathrm{uIU} / \mathrm{mL})$ & $13.60 \pm 14.50$ & 9.60 & 4 & 100 \\
hs-CRP $(\mathrm{mg} / \mathrm{L})$ & $2.10 \pm 1.60$ & 1.70 & 0.36 & 9.30 \\
Creatinine $(\mathrm{mg} / \mathrm{dL})$ & $0.94 \pm 0.10$ & 0.90 & 0.70 & 1.30 \\
eGFR (minute/1.73m $)$ & $98.10 \pm 15.30$ & 100 & 64 & 128 \\
GPx activity $(\mathrm{U} / \mathrm{gHb})$ & $48.10 \pm 13.40$ & 46.30 & 28 & 107 \\
tCys ( $\mu$ mol/L) & $250.20 \pm 44.80$ & 242 & 175.70 & 362.30 \\
HOMA-IR & $3.20 \pm 3.40$ & 2.30 & 0.80 & 24.70 \\
\hline
\end{tabular}

BMI: body mass index, SD: standard deviation. 
Table 2. Correlation of GGT, hs-CRP, GPx activity, tCys and HOMA-IR in different groups.

\begin{tabular}{|c|c|c|c|c|c|c|c|c|}
\hline \multirow{2}{*}{ Variable } & \multirow{2}{*}{ Group } & \multicolumn{7}{|c|}{$p(*)$} \\
\hline & & Mean \pm SD & G I \& G II & G I \& G III & G I \& G IV & G II \& G III & G II \& G IV & G III \& G IV \\
\hline \multirow{4}{*}{ GGT } & $1(n=33)$ & $42.3 \pm 30.7$ & 0.492 & 0.246 & 0.276 & 0.348 & 0.348 & 0.459 \\
\hline & II $(n=5)$ & $36.6 \pm 15.3$ & & & & & & \\
\hline & III (n=17) & $42.9 \pm 21.7$ & & & & & & \\
\hline & IV $(n=17)$ & $49.6 \pm 39.5$ & & & & & & \\
\hline \multirow{4}{*}{ hs-CRP } & $1(n=33)$ & $2.1 \pm 1.9$ & 0.423 & 0.500 & 0.062 & 0.453 & 0.136 & 0.046 \\
\hline & II $(\mathrm{n}=5)$ & $1.7 \pm 1.4$ & & & & & & \\
\hline & III (n=17) & $1.7 \pm 0.9$ & & & & & & \\
\hline & IV $(n=17)$ & $2.6 \pm 1.6$ & & & & & & \\
\hline \multirow{4}{*}{ GPx activity } & $1(n=33)$ & $50.1 \pm 11.6$ & 0.018 & 0.464 & 0.009 & 0.019 & 0.145 & 0.021 \\
\hline & II $(n=5)$ & $38.9 \pm 6.9$ & & & & & & \\
\hline & III (n=17) & $53.2 \pm 17.7$ & & & & & & \\
\hline & IV $(n=17)$ & $41.8 \pm 7.7$ & & & & & & \\
\hline \multirow{4}{*}{ tCys } & $1(n=33)$ & $250.9 \pm 51.1$ & 0.341 & 0.403 & 0.360 & 0.306 & 0.164 & 0.309 \\
\hline & II $(n=5)$ & $258.1 \pm 49.0$ & & & & & & \\
\hline & III (n=17) & $253.4 \pm 45.2$ & & & & & & \\
\hline & IV $(n=17)$ & $243.2 \pm 31.5$ & & & & & & \\
\hline \multirow{4}{*}{ HOMA-IR } & I $(n=33)$ & $2.8 \pm 2.9$ & 0.341 & 0.166 & 0.017 & 0.184 & 0.074 & 0.172 \\
\hline & II $(n=5)$ & $2.1 \pm 1.2$ & & & & & & \\
\hline & III (n=17) & $3.9 \pm 2.7$ & & & & & & \\
\hline & IV $(n=17)$ & $3.7 \pm 2.0$ & & & & & & \\
\hline
\end{tabular}

*: Mann Whitney analysis; G I: Group I, G II: Group II, G III: Group III, G IV: Group IV; Significant $p$ values were marked in bold.

Table 3. Correlation of GGT, hs-CRP, GPx activity, tCys and HOMA-IR in each group.

\begin{tabular}{|c|c|c|c|c|c|c|c|c|c|c|}
\hline \multirow{2}{*}{ Correlation between } & \multicolumn{2}{|c|}{ Total $(n=72)$} & \multicolumn{2}{|c|}{ G I (n=33) } & \multicolumn{2}{|c|}{ G II (n=5) } & \multicolumn{2}{|c|}{ G III (n=17) } & \multicolumn{2}{|c|}{ G IV $(n=17)$} \\
\hline & $\mathbf{r}$ & $p(*)$ & $\mathbf{r}$ & $p(*)$ & $\mathbf{r}$ & $p(*)$ & $\mathbf{r}$ & $p(*)$ & $\mathbf{r}$ & $p\left({ }^{*}\right)$ \\
\hline GGT with hs-CRP & 0.129 & 0.140 & 0.096 & 0.297 & 1.000 & 0.000 & 0.073 & 0.391 & 0.068 & 0.398 \\
\hline GGT with GPx & -0.081 & 0.250 & -0.172 & 0.169 & 0.100 & 0.436 & -0.326 & 0.101 & 0.307 & 0.116 \\
\hline GGT with t-Cys & -0.121 & 0.156 & -0.183 & 0.153 & 0.700 & 0.094 & -0.129 & 0.311 & -0.301 & 0.120 \\
\hline GGT with HOMA-IR & 0.179 & 0.066 & -0.018 & 0.460 & 0.100 & 0.436 & 0.018 & 0.472 & 0.604 & 0.005 \\
\hline hs-CRP with HOMA-IR & 0.134 & 0.131 & 0.182 & 0.155 & 0.100 & 0.436 & 0.124 & 0.318 & -0.027 & 0.459 \\
\hline GPx activity with HOMA-IR & -0.121 & 0.156 & -0.219 & 0.111 & 0.200 & 0.374 & 0.167 & 0.261 & 0.022 & 0.467 \\
\hline tCys with HOMA-IR & -0.129 & 0.141 & -0.093 & 0.304 & 0.600 & 0.142 & -0.098 & 0.354 & -0.415 & 0.049 \\
\hline
\end{tabular}

*: Spearman correlation analysis; G I: Group I, G II: Group II, G III: Group III, G IV: Group IV; Significant $p$ values were marked in bold. 


\section{Relations between GGT, hs-CRP, GPx activity, tCys and HOMA-IR}

Significant difference of HOMA-IR between group I and IV $(\mathrm{p}=0.017)$ was obtained (Table 2). Meanwhile, significant correlation between GGT and HOMA-IR and significant negative correlation between tCys with HOMA-IR in Group IV, were shown in Table 3.

\section{Discussion}

Combination of obesity with less physical activity and excessive caloric consumption would induce insulin resistance.(17) Most subjects with central obesity have insulin resistance characteristic, but not all obese would have insulin resistance syndrome.(18) GGT was reported to be associated with insulin resistance with markers of fasting insulin and HOMA-IR.(3,19-21) In our current study, we found that GGT and HOMA-IR were significantly correlated in Group IV. Therefore, our results confirmed the previous reports, suggesting that GGT could be associated with insulin resistance, due to adiposity and ectopic fat in the liver in obese subjects.(22) In addition, our ultrasonographic results showed that subjects with higher fatty liver grade were found in Group IV comparing to Group II.

There were not significant correlations of GGT and hs-CRP, GGT and GPx, GGT and tCys, hs-CRP and HOMA-IR, GPx and HOMA-IR, since we found that our subject were included in hs-CRP middle risk (1.00-3.00 $\mathrm{mg} / \mathrm{L}$ ) and reference range of GPx activity (27.5-73.6 U/ $\mathrm{gHb}$ ), suggesting that there was a homeostatic mechanism. Insulin resistance-associated obesity with excessive release of non-esterified fatty acid (NEFA) from adipose tissue into plasma and accumulated in liver, can impair insulin sensitivity.(1,3) In addition, a study conducted in children and adolescent showed positive association between tCysNEFA and tCys-HOMA-IR. Subjects with high tCys have double-risk of insulin resistance.(11) But interestingly, in our current study, we found a significant negative correlation between tCys with HOMA-IR in Group IV. We assume that cysteine dioxygenase homeostasis mechanism might be involved, Cysteine dioxygenase has been reported to have an important role in controlling tCys level.(11) Additionally since Group IV consist of subject with non-alcoholic fatty liver disease, which means they have lower concentration of total glutathione as a results of oxidant stress, and also and lower concentrations of cysteine-glutathione disulfide. This may results the false negative correlation between tCys with HOMA-IR.

\section{Conclusion}

In summary, GGT was significantly positive-correlated with HOMA-IR in men with $\mathrm{WC}>100 \mathrm{~cm}$ and fatty liver. Further investigation with more subjects is necessary to determine clear GGT cut-off to distinguish subjects with fatty liver and insulin resistance.

\section{Acknowledgement}

We thank the Prodia Education and Research Institute for invaluable support.

\section{References}

1. Kirk EP, Klein S. Pathogenesis and pathophysiology of the cardiometabolic syndrome. J Clin Hypertens (Greenwich). 2009; 11: 761-5.

2. Emdin M, Pompella A, Paolicchi A. Gamma-glutamyltranferase, Atherosclerosis, and cardiovascular disease: triggering oxidative stress within the plaque. Circulation. 2005; $112: 2078-80$.

3. Whitfield JB. Gamma glutamyl transferase. Crit Rev Clin Lab Sci. 2001; 38: 263-355.

4. Onat A, Can G, Örnek E, Çiçek G, Ayhan E, Doğan Y. Serum $\gamma$-glutamyltransferase: independent predictor of risk of diabetes, hypertension, metabolic syndrome and coronary disease. Obesity (Silver Spring). 2012; 20: 842-8.

5. Lee DH, Blomhoff R, Jacobs DR Jr. Is serum gamma glutamyltransferase a marker of oxidative stress? Free Radic Res. 2004; 38: 535-9.

6. Giral P, Jacob N, Dourmap C, Hansel B, Carrié A, Bruckert E, et al. Elevated gamma-glutamyltransferase activity and perturbed thiol profile are associated with features of metabolic syndrome. Arterioscler Thromb Vasc Biol. 2008; 28: 587-93.

7. Gunawan S, Santoso A, Wijaya A. The correlation of gamma glutamyl transferase (GGT), glutathione peroxidase (GPx) and total antioxidant status (TAS) with inflammatory marker in individuals with metabolic syndrome. Indones Biomed J. 2011; 3: 57-63.

8. Bastard JP, Maachi M, Lagathu C, Kim MJ, Caron M, Vidal H, et al. Recent advances in relationship between obesity, inflammation and insulin resistance. Eur Cytokine Netw. 2006; 17: 4-12.

9. Tripathy D, Mohanty P, Dhindsa S, Syed T, Ghanim H, Aljada A, et $a l$. Elevation of free fatty acids induces inflammation and impairs vascular reactivity in healthy subjects. Diabetes. 2003; 52: 2882-7.

10. Schenk S, Saberi M, Olefsky JM. Insulin sensitivity: Modulation by nutrients and inflammation. J Clin Invest. 2008; 118: 2992-3002.

11. Elshorbagy AK, Valdivia-Garcia M, Refsum H, Butte N. The Association of cysteine with obesity, inflammatory cytokines and insulin resistance in Hispanic children and adolescents. Plos One. 2012; 7: e44166.

12. Ridker PM. Clinical application of C-reactive protein for cardiovascular disease detection and prevention. Circulation. 2003; 107: 363-9.

13. Jialal I, Devaraj S. Inflammation and atherosclerosis: the value of the high-sensitivity C-reactive protein assay as a risk marker. Am J Clin Pathol. 2001; 116 Suppl: S108-15

14. Fernández-SánchezA, Madrigal-Santillán E, Bautista M, Esquivel-Soto 
J, Morales-González A, Esquivel-Chirino C, et al. Inflammation, oxidative stress, and obesity. Int J Mol Sci. 2011; 12: 3117-32.

15. Forgione MA, Cap A, Liao R, Moldovan NI, Eberhardt RT, Lim CC, et $a l$. Heterozygous cellular glutathione peroxidase deficiency in the mouse: abnormalities in vascular and cardiac function and structure. Circulation. 2002; 106: 1154-8.

16. Elshorbagy AK, Smith AD, Kozich V, Refsum H. Cysteine and Obesity. Obesity (Silver Spring). 2011; 20: 473-81.

17. Cornier MA, Dabelea D, Hernandez TL, Lindstrom RC, Steig AJ, Stob NR, et al. The metabolic syndrome. Endocr Rev. 2008; 29: 777-822.

18. Després JP, Lemieux I,. Abdominal obesity and metabolic syndrome. Nature. 2006; 444: 881-7.

19. Nilssen O, Førde OH. Seven-year longitudinal population study of change in gamma-glutamyltransferase : the Tromso Study. Am J Epidemiol. 1994; 139: 787-92.

20. Kawamoto R, Kohara K, Tabara Y, Miki T, Otsuka N. Serum gammaglutamyl transferase levels are associated with metabolic syndrome in community-dwelling individuals. J Atheroscler Thromb. 2009; 16: 355-62.

21. André P, Balkau B, Vol S, Charles MA, Eschwège E, DESIR Study Group. Gamma-glutamyltransferase activity and development of the metabolic syndrome (International Diabetes Federation Definition) in middle-aged men and women: Data from the Epidemiological Study on the Insulin Resistance Syndrome (DESIR) cohort. Diabetes Care. 2007; 30: 2355-61.

22. Marchesini G, Brizi M, Bianchi G, Tomassetti S, Bugianesi E, Lenzi $\mathrm{M}$, et al. Nonalcoholic fatty liver disease: a feature of the metabolic syndrome. Diabetes. 2001; 50: 1844-50. 